КЛІНІКО-ФУНКЦІОНАЛЬНІ ОСОБЛИВОСТІ ПЕРЕБІГУ ХРОНІЧНОГО
ОБСТРУКТИВНОГО ЗАХВОРЮВАННЯ ЛЕГЕНЬ У ОСІБ ІЗ ВПЕРШЕ
ВИЯВЛЕНИМ ЗАХВОРЮВАННЯМ ЗАЛЕЖНО ВІД СТАТІ ТА ВІКУ

\title{
H.В. Черепій
}

Вінницький національний медичний університет ім. М.І. Пирогова, м. Вінниця, Україна

\begin{abstract}
Ключові слова: хронічне обструктивне захворювання легень, рання діагностика, поширеність ХОЗЛ, кашель, задишка.
\end{abstract}

Буковинський медичний вісник. T.21, № 3 (83). C. 114-122

DOI:

10.24061/2413-0737.

XXI.3.83.2017.104

E-mail: cherepiin@gmail.com
Хронічне обструктивне захворювання легень (ХОЗЛ) залишається однією з найважливіших медичних і сочіальних проблем, яка характеризується широкою поширеністю, високими показниками смертності, інвалідності та значним економічним збитком.

Мета роботи - встановити клініко-функціональні особливості перебігу ХОЗЛ у осіб із вперше виявленим захворюванням залежно від статі та віку.

Матеріал і методи. У ході дослідження за допомогою оригінальної анкети, створеної на основі опитувальників GOLD (2012, 2015 рр.) та наказу МОЗ України № 555 від 27.06.2013 р., залежно від вираженості клінічних проявів респіраторних симптомів та факторів ризику виникнення ХОЗЛ, ми відібрали групу пацієнтів із високим ризиком розвитку ХОЗЛ. До групи увійшли 216 осіб (41,1\%), щуо вважали себе здоровими та регулярно, двічі на рік, проходили медичні огляди, серед них було 115 жінок (53,2%) та 101 чоловік (46,8\%).

Результати. Встановлено, шо серед обстежених у 79 (58,1%) паціснтів за результатами спірографії виявлено зниження індексу

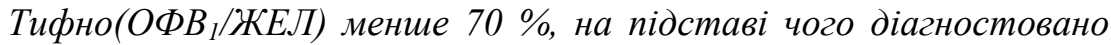
вперше виявлений ХОЗЛ. Порівнявши групи пацієнтів з виявленим ХОЗЛ та без нього можна сказати, щзо достовірність різниці між кількістю чоловіків та жінок, віком обстежених відзначалися лише у групі осіб з виявленим ХОЗЛ віком 61-79 років. У чій групі чоловіків було 9 (28,1\%), достовірно більше ніж жінок - 2 (4,3\%, $p=0,001)$.

Порівнювалася також частота основних факторів ризику розвитку ХОЗЛ. На респіраторні захворювання хворіли всі опитані. Достовірної різниці між чоловіками та жінками в обох групах не було. У групі з ХОЗЛ обтяжений алергічний анамнез відзначали дещзо частіше жінки (71,9\%), ніж чоловіки (61,7\%). У групі без ХОЗЛ цей фактор ризику теж частіше відзначали жінки (91,7\%), ніж чоловіки (72,7\%). В осіб із вперше діагностованим ХОЗЛ чоловіків, щзо палили, було 34 (72,3\%) та жінок - 8 (25\%, p=0,001). Серед осіб без діагностованого ХОЗЛ палили 21 чоловік (63,6 \%) та 2 жінки (8,3\%), (p=0,001). Статева структура пацієнтів із вперше виявленим ХОЗЛ залежно від ступеня тяжкості була такою: із GOLD 1 було 15 чоловіків (19,0\%) та 6 жінок (7,6\%); із GOLD 2 було 14 чоловіків (17,7 \%) та 12 жінок (15,2\%); із GOLD 3 було 16 чоловіків (20,2\%) та 12 жінок (15,2\%); із GOLD 4 було 2 чоловіків (2,5\%) та 2 жінки (2,5\%).

Висновки. Встановлено, щуо серед обстежених у 79 (58,1\%) пацієнтів за результатами спірографії виявлено зниження індексу Тифно (ОФВ1/ЖЕЛ) менше $70 \%$, на підставі чого вперше встановлений діагноз хронічного обструктивного захворювання легень. 
Original research

\begin{abstract}
Ключевые слова: хроническое обструктивное заболевание легких, ранняя диагностика, распространенность ХОЗЛ, кашель, одыикка.
\end{abstract}

Буковинский медицинский весник. T.21, № 3 (83). C. 114-122

\section{КЛИНИКО-ФУНКЦИОНАЛЬНЫЕ ОСОБЕННОСТИ ТЕЧЕНИЯ ХРОНИЧЕСКОГО ОБСТРУКТИВНОГО ЗАБОЛЕВАНИЯ ЛЕГКИХ У ЛИЦ С ВПЕРВЫЕ ВЫЯВЛЕННЫМ ЗАБОЛЕВАНИЕМ В ЗАВИСИМОСТИ ОТ ПОЛА И ВОЗРАСТА H.В. Черепий}

Хроническое обструктивное заболевание легких (ХОЗЛ) остается одной из важнейших медицинских и социальных проблем, которая характеризуется широкой распространенностью, высокими показателями смертности, инвалидности и значительным экономическим ущербом.

Цель работы - установить клинико-функииональные особенности течения ХОЗЛ у лии с впервые выявленным заболеванием в зависимости от пола и возраста.

Материал и методы. В ходе исследования с помощью оригинальной анкеты, созданной на основе опросников $\operatorname{GOLD}(2012,2015)$ и приказом МЗ Украины № 555 от 27.06.2013 г. , в зависимости от выраженности клинических проявлений респираторных симптомов и факторов риска возникновения ХОЗЛ, мы отобрали группу пациентов с высоким риском развития ХОЗЛ. В группу вошли 216 человек (41,1\%), которые считали себя здоровыми и регулярно, дважды в год, проходили медицинские осмотры, среди них было 115 женщин (53,2\%) и 101 мужчина (46,8\%).

Результаты. Установлено, что среди обследованных в 79 $(58,1 \%)$ пациентов по результатам спирографии выявлено снижение индекса Тифно (ОФВ1 / ЖЕЛ) менее $70 \%$ и диагностировано впервые обнаруженное ХОЗЛ. Сравнив группь пациентов с выявленным ХОЗЛ и без него, установлено, что достоверная разница между количеством мужчин и женщин в возрасте обследованных отмечалась только в группе лии с выявленным ХОЗЛ в возрасте 61-79 лет. В этой группе мужчин было 9 (28,1\%), достоверно больше чем женшин - $2(4,3 \%, p=0,001)$. Сравнивалась также частота основных факторов риска развития ХОЗЛ. Респираторными заболеваниями болели все опрошенные. Достоверной разнищы между мужчинами и женщинами в обеих группах не было. В группе с ХОЗЛ отягощенный аллергический анамнез отмечали несколько чаще женщины (71,9\%), чем мужчины (61,7\%). В группе без ХОЗЛ этот фактор риска тоже чаще отмечали женщины (91,7\%), чем мужчины (72,7\%). У лии с впервые диагностированнылм ХОЗЛ курящих мужчин было 34 (72,3\%) и женщин - $8(25 \%$, $p=0,001)$. Среди лии без диагностированного ХОЗБЛ курили 21 мужчина (63,6 \%) и 2 женщины $(8,3 \%, p=0,001)$. Половая структура пачиентов с впервые выявленным ХОЗЛ в зависимости от степени тяжести была следующей: с GOLD 1 было 15 мужчин (19,0\%) и 6 женщин (7,6\%); с GOLD 2 было 14 мужчин (17,7\%) и 12 женщиин (15,2\%); с GOLD 3 было 16 мужчин (20,2\%) и 12 женщин (15,2\%); с GOLD 4 было 2 мужчин (2,5\%) и 2 женщины $(2,5 \%)$.

Выводы. Установлено, что среди обследованных в 79 (58,1\%) паичентов по результатам спирографии было вылялено снижение индекса Тифно (ОФВ1 / ЖЕЛ) менее 70 \% и на основании этого впервые установлен диагноз хронического обструктивного заболевания легких. 
Оригінальні дослідження

Key words: Chronic obstructive pulmonary disease, early diagnosis, COPD prevalence, cough, dyspnea.

Bukovinian Medical Herald. T.21, № 3 (83). P. 114-122

\section{CLINICAL AND FUNCTIONAL FEATURES OF NEWLY DIAGNOSED CHRONIC OBSTRUCTIVE PULMONARY DISEASE COURSE IN PATIENTS, DEPENDING ON GENDER AND AGE N.V. Cherepii}

Abstract. Introduction: Chronic obstructive pulmonary disease (COPD) remains one of the most challenging medical and social problems, characterized by large-scale prevalence, high mortality rates, disability and significant economic losses.

Objective: to establish the special features of clinical and functional course of COPD in individuals with the first established diagnosis of the disease, depending on their gender and age.

Materials and methods: During the study, we screened a group of patients at high risk of developing COPD with the help of original questionnaire, created on the basis of GOLD questionnaires (2012, 2015) and Order of the Ministry of Health of Ukraine No. 555 of June 27, 2013 [6, 7], depending on the severity of clinical manifestations of respiratory symptoms and COPD risk factors. The group consisted of 216 individuals (41,1\%) including 115 female (53,2\%) and 101 male $(46,8 \%)$ subjects, who considered themselves healthy and regularly passed medical examinations twice a year.

The results: We found that among 79 (58,1 \%) examined patients, according to spirography reports, the Tifno index (FEVI/FVC) was decreased by at least $70 \%$ which showed that they had newly diagnosed COPD. Having compared the groups of patients with and without COPD, we can definitely say about statistically significant difference between the number of male and female individuals, and age differences only in agroup of 61-79 individuals with COPD. This group consisted of significantly more males $9(28,1 \%)$ than females - 2 $(4,3 \%),(p=0,001)$.We compared the incidence of major COPD risk factors. All respondents had a history of respiratory diseases. There was no statistically significant difference between men and women in both groups. In the COPD group, an allergic-burdened history was reported rather by women (71,9\%) than men $(61,7 \%)$. In the nonCOPD group, this risk factor was also more often reported by women $(91,7 \%)$ than men $(72,7 \%)$. Among individuals with newly diagnosed COPD, 34 (72,3\%) male individuals and 8 (25\%) female ones were smokers, $(p=0,001)$. Among non-COPD individuals, 21 male subjects $(63,6 \%)$ and 2 female subjects $(8,3 \%),(p=0,001)$ were smokers. The gender ratio of patients with newly diagnosed COPD, depending on the disease severity, was as follows: GOLD 1 presented 15 men (19,0\%) and 6 women (7,6\%); GOLD $2-14$ men (17,7\%) and 12 women (15,2\%); GOLD 3 - 16 men (20,2\%) and 12 women (15,2\%); and GOLD 4- 2 men (2,5\%) and 2 women (2,5\%).

Conclusions: It was found that among the examined patients in 79 $(58,1 \%)$ patients, spirography revealed a decrease of Tifno index (FEV1/FVC) by less than $70 \%$ and was considered as the first diagnosis of chronic obstructive pulmonary disease.
Вступ. Хронічне обструктивне захворювання легень (ХОЗЛ) залишається однією з найважливіших медичних і соціальних проблем, яка характеризується широкою поширеністю, високими показниками смертності, інвалідності та значним економічним збитком $[1,2]$. За даними Європейського респіраторного товариства (ERS), прогнозується зростання смертності від ХОЗЛ до 2020 року, коли вона вийде на 4-те місце після таких захворювань, як ішемічна хвороба серця (IXC), 
Original research

цереброваскулярна патологія, рак легень. Така тенденція характерна як для Східної, так і для Західної Європи. Всесвітня організація охорони здоров'я (ВООЗ) прогнозує, що до 2030 року ХОЗЛ стане третьою найбільш поширеною причиною смертей після інсульту та інфаркту міокарда $[1,3]$.

До факторів ризику ХОЗЛ належать паління, несприятливі умови професійної діяльності та життя, інфекційні чинники, обтяжений сімейний та алергологічний анамнез, погодні умови і кліматичні чинники (туман та підвищена вологість) [4].

Захворювання спостерігається значно частіше у курців і колишніх курців, ніж у осіб, що не курять; в осіб старше 40 років порівняно з більш молодими; частіше у чоловіків, ніж у жінок; серед міських жителів майже вдвічі частіше, ніж у жителів сільської місцевості [5]. Однозначно всі науковці та клініцисти наголошують на низький рівень діагностики ХОЗЛ. Так, за даними популяційних скринінгових досліджень, серед осіб із вперше виявленим ХОЗЛ тільки у 20 \% був поставлений цей діагноз раніше [6].

Враховуючи, що ХОЗЛ діагностують частіше в осіб старше 40 років, перебіг захворювання, як правило, проходить на фоні інших хронічних захворювань внутрішніх органів. Таке поєднання зумовлює подібність симптомів та пізню діагностику захворювання. У той же час існують особливості клінічного перебігу ХОЗЛ серед чоловіків та жінок. Відомо, що захворювання має різний вплив на параметри якості життя (ЯЖ) залежно від статі $[2,7]$. Таким чином, проблема ранньої діагностики ХОЗЛ $\epsilon$ однією $з$ актуальних та потребує розроблення методичних підходів.

Мета роботи. Встановити клінікофункціональні особливості перебігу ХОЗЛ у осіб із вперше виявленим захворюванням залежно від статі та віку.

Матеріал і методи. У ході дослідження за допомогою оригінальної анкети, створеної на основі опитувальників GOLD (2012, 2015 рр.)та наказу МОЗ України № 555 від 27.06.2013 р. [8, 9], залежно від вираженості клінічних проявів респіраторних симптомів та факторів ризику виникнення ХОЗЛ, ми відібрали групу пацієнтів із високим ризиком розвитку ХОЗЛ. До групи увійшли 216 осіб (41,1\%), що вважали себе здоровими та регулярно, двічі на рік, проходили медичні огляди, серед них було 115 жінок (53,2 \%) та 101 чоловік $(46,8 \%)[5,7]$ (рис. 1$)$.

Найбільш численною групою пацієнтів із високим ступенем вірогідності ХОЗЛ є особи активного працездатного віку (до 60 років). У віковій групі до 40 років пацієнтів із високим ризиком розвитку ХОЗЛ було всього 72 особи $(33,3 \%)$, практично однаково чоловіків та жінок, відповідно 35 (34,7\%) та 37 (32,2\%).У групі обстежених 41-49 років було 55 осіб $(25,5 \%)-30$ чоловіків $(29,7 \%)$ та 25 жінок $(21,7 \%)$ та в групі
50-59 років - 57 осіб (26,4\%), а саме 26 чоловіків $(25,7 \%)$ та 31 жінка $(27,0 \%)$ (рис. 1$)$.

Пацієнтам із високим ризиком виникнення ХОЗЛ проведена спірографія з бронходилатаційним тестом із використанням 400 мкг сальбутамолу та проведено опитування за модифікованою анкетою оцінки задишки медичної дослідницької ради (мМДР) та тестом з оцінки ХОЗЛ (ТОХ) для визначення клінічної групи ХОЗЛ, що регламентовано наказом МОЗ України № 555 від 27.05.2013 р. [8, 9].

Параметри якості життя (ЯЖ) у пацієнтів 3 високим ризиком ХОЗЛ, досліджували за допомогою Української версії (переклад та адаптація до України) Міжнародного опитувальника з якості життя Medical Outcomes Study Short Form (MOS SF-36). Він користується найбільшою популярністю саме завдяки тому, що дає змогу оцінити ЯЖ респондентів із різними нозологіями та порівняти показники із популяцією здорових осіб віком від 14 років та старше.

Опитувальник орієнтований на визначення восьми комплексних параметрів ЯЖ, які найбільш часто використовуються в популяційних дослідженнях та найбільш чутливі до змін стану здоров'я людини. Досліджували такі критерії оцінки ЯЖ: фізична активність (ФА); роль фізичних проблем в обмеженні життєдіяльності (РФ); біль (Б); загальне здоров'я (33); життєздатність (ЖЗ); соціальна активність (СА); роль емоційних проблем в обмеженні життєдіяльності (РЕ); психічне здоров'я (ПЗ); порівняння самовідчуття 3 попереднім роком (ПС) . ФА, РФ та Б - відповідають фізичному компоненту здоров'я, СА, РЕ та ПЗ - характеризують психологічний компонент, ЖЗ та 33 - корелюють з обома компонентами, ПС дає змогу прослідкувати динаміку здоров'я протягом року [4].

У процесі дослідження аналізували розподілення параметрів ЯЖ залежно від статі, віку, ступеня тяжкості ХОЗЛ, вираженості клінічних симптомів захворювання.

Обстежено 136 пацієнтів віком від 38 до 77

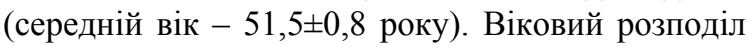
обстежених продемонстрував, що достовірно найбільша частка обстежених була віком до 50 років $(\mathrm{p}<0,0001)$ і найменша частка - віком старше 70 років $(\mathrm{p}<0,006)$. Серед обстежених 81 (59,6 \%) чоловік і 55 (40,4 \%) жінок. Співвідношення чоловіків до жінок 1,5 до 1,0 демонструє, що в дослідженні суттєво переважали пацієнти чоловічої статі.

Статистичну обробку отриманих результатів виконували на персональному комп'ютері за допомогою методів варіаційної статистики з використанням програм MicroSoft Excel 2003 iStatSoft „Statistica” v. 6.1, (Ліцензійна версія №BXXR901E246022FA належить медикоді ігностичному центру Вінницького національного медичного університету ім. M.I. Пирогова), згідно з рекомендаціями [11]. Вірогід- 
Оригінальні дослідження

ними вважали результати порівнянь при значенні ймовірності похибки $\mathrm{p}<0,05$.

Результати дослідження та їх обговорення. Встановлено, що серед обстежених у 79 (58,1\%) пацієнтів за результатами спірографії виявлено зниження індексу Тифно (ОФВ 1 ЖЕЛ) менше $70 \%$ та діагностовано вперше ХОЗЛ.

Порівнявши групи пацієнтів із встановленим ХОЗЛ та без нього, можна дійти висновку, що достовірність різниці між кількістю чоловіків та жінок, віком обстежених відзначалися лише у групі осіб із виявленим ХОЗЛ віком 61-79 років. У цій групі чоловіків було $9(28,1 \%)$, достовірно більше, ніж жінок $-2(4,3 \%),(\mathrm{p}=0,001)$.

Ми порівняли частоту основних факторів ризику розвитку ХОЗЛ у цих же групах (табл. 1).

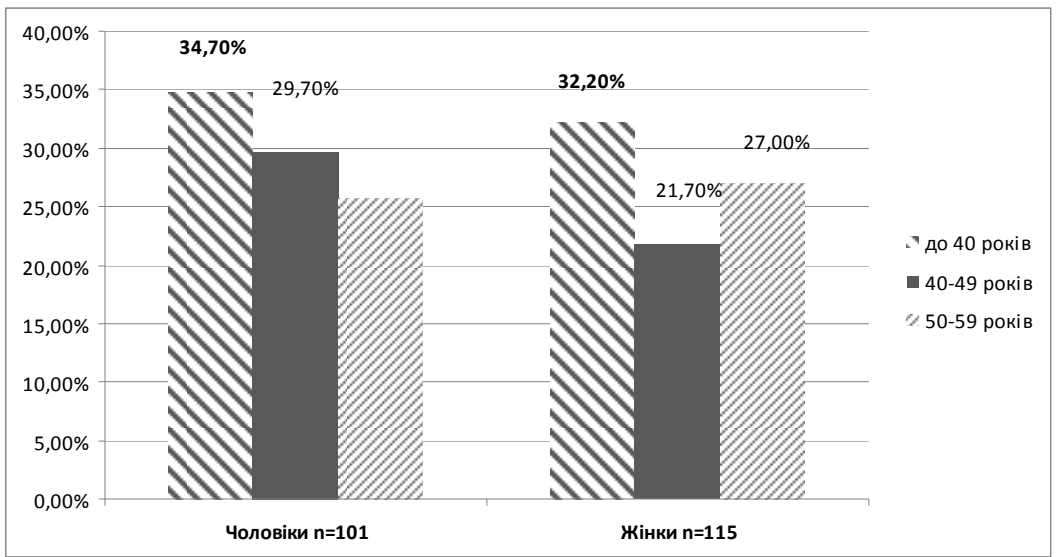

Рис. 1. Статево-вікова характеристика проанкетованих пацієнтів із високим ризиком розвитку хронічного обструктивного захворювання легень

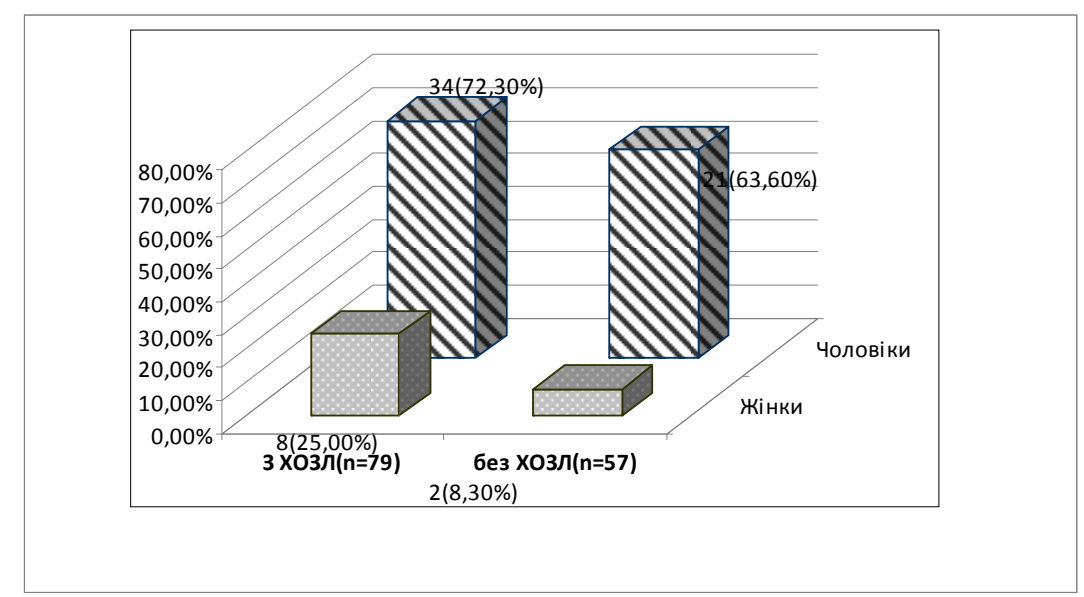

Рис. 2. Частка осіб, що палять, серед чоловіків та жінок у групі пацієнтів із вперше виявленим хронічним обструктивним захворюванням легень та без нього

Таблиця 1

Оцінка факторів ризику хронічного обструктивного захворювання легень серед паціснтів у групах із вперше виявленим захворюванням та паціснтами без хронічного обструктивного захворювання легень

\begin{tabular}{|c|c|c|c|c|c|c|}
\hline & \multicolumn{2}{|c|}{ З ХОЗЛ } & \multirow{2}{*}{$\mathrm{P}$} & \multicolumn{2}{|c|}{ Без ХОЗЛ } & \multirow{2}{*}{ P } \\
\cline { 1 - 3 } & $\begin{array}{c}\text { Чоловіки } \\
(\mathrm{n}=47)\end{array}$ & Жінки $(\mathrm{n}=32)$ & & $\begin{array}{c}\text { Чоловіки } \\
(\mathrm{n}=33)\end{array}$ & Жінки $(\mathrm{n}=24)$ & \\
\hline Паління & $34(72,3 \%)$ & $8(25,0 \%)$ & 0,0002 & $21(63,6 \%)$ & $2(8,3 \%)$ & 0,0001 \\
\hline $\begin{array}{c}\text { Респіраторні за- } \\
\text { хворювання }\end{array}$ & $47(100 \%)$ & $32(100 \%)$ & & $33(100 \%)$ & $24(100 \%)$ & \\
\hline $\begin{array}{c}\text { Алергологічний } \\
\text { анамнез }\end{array}$ & $29(61,7 \%)$ & $26(71,9 \%)$ & 0,64 & $24(72,3 \%)$ & $22(91,7 \%)$ & 0,20 \\
\hline
\end{tabular}

Примітка. 1. Порівняння відсотків між групами проведено за критерієм $\chi^{2} .2$. Порівняння величин загального бала між групами проведено за Mann-Whithney U test. 3. Різниця достовірна при $\mathrm{p}<0,05$ 
Original research

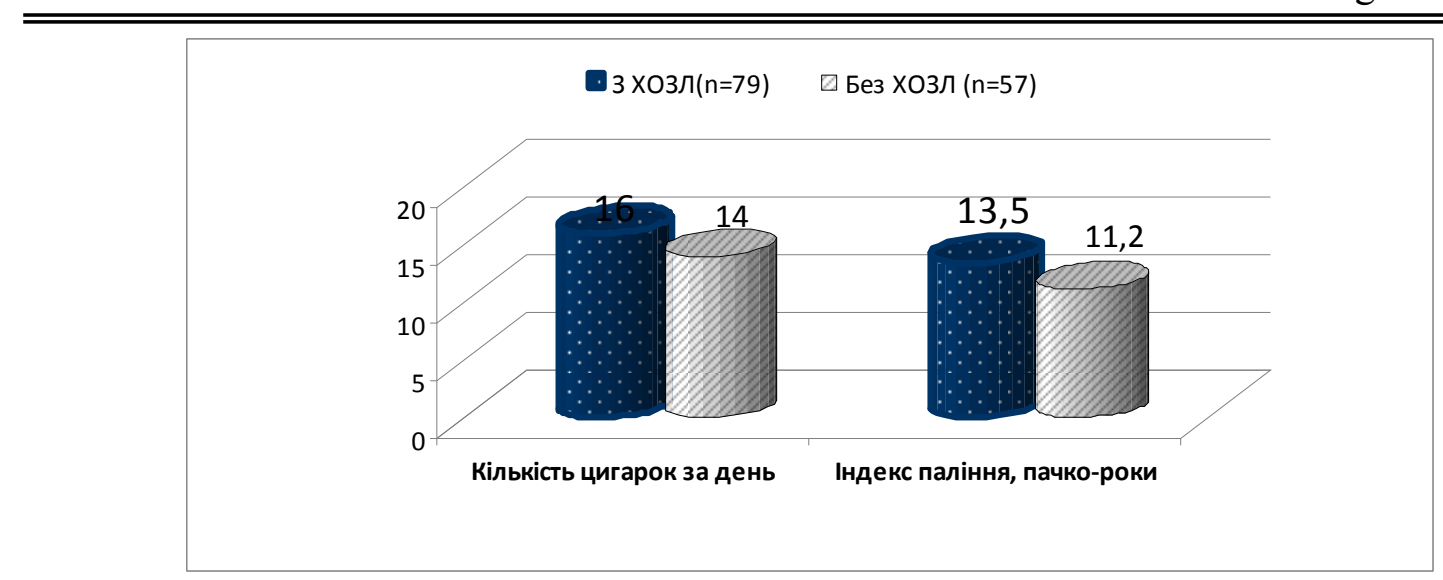

Рис. 3. Кількість цигарок за день та індекс паління в осіб з вперше виявленим хронічним обструктивним захворюванням легень та без нього

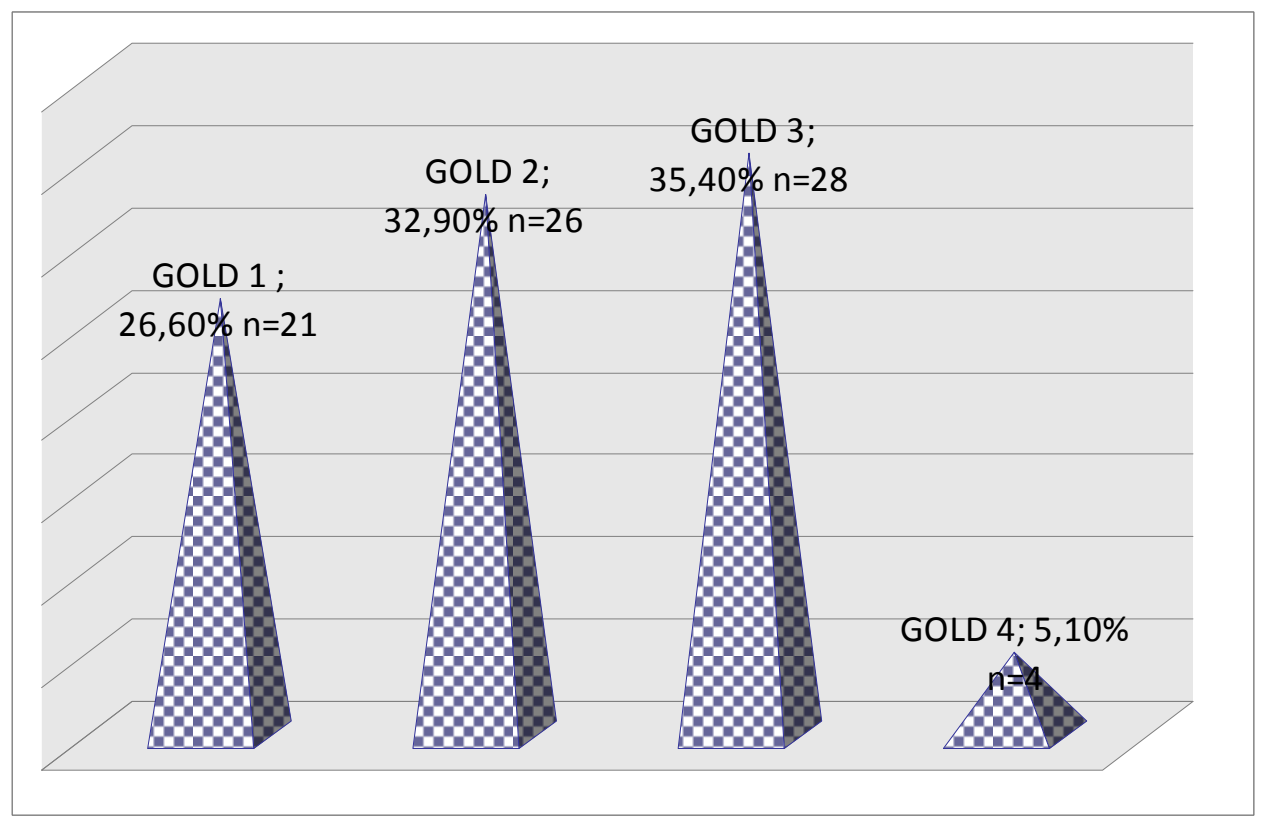

Рис. 4. Ступінь тяжкості хронічного обструктивного захворювання легень у осіб із вперше діагностованим захворюванням

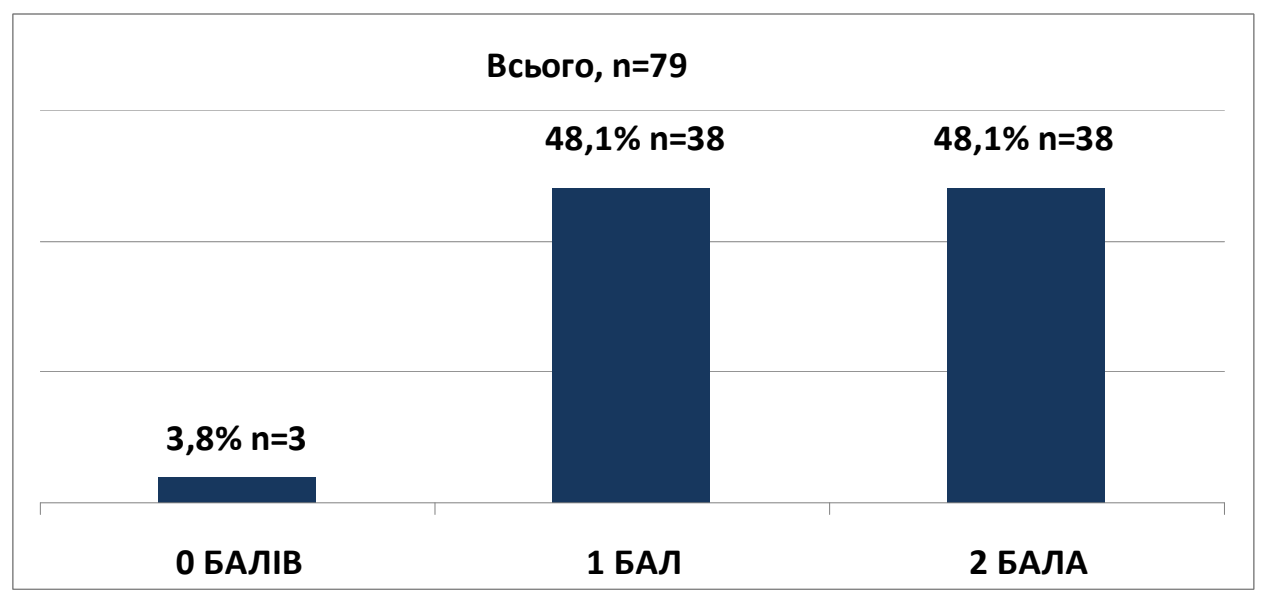

Рис. 5. Ступінь задишки за шкалою мMDRy пацієнтів із виявленим хронічним обструктивним захворюванням легень

На часті респіраторні захворювання хворіли всі опитані. Достовірної різниці між чоловіками та жінками в обох групах не виявлено.
Алергологічний анамнез обтяжений у 52 $(65,8 \%)$ пацієнтів з ХОЗЛ та у $64(80,7 \%)$ осіб без встановленого діагнозу ХОЗЛ. У групі 3 ХОЗЛ обтяжений алергологічний анамнез відзна- 
Оригінальні дослідження

чали дещо частіше жінки (71,9 \%), ніж чоловіки $(61,7 \%)$. У групі без ХОЗЛ цей фактор ризику теж частіше відзначали жінки $(91,7 \%)$, ніж чоловіки $(72,7 \%)$.

Аналізуючи скаргу на паління, слід відзначити, що цю скаргу пред'являли 53 особи $(67,1$ \%) з вперше виявленим ХОЗЛ та 49 (28,1 \%) без визначеного ХОЗЛ $(\mathrm{p}=0,001)$. Встановлено, що в обох групах чоловіків було достовірно більше, ніж жінок $(p=0,0002)$. В осіб із вперше діаг- ностованим ХОЗЛ чоловіків, що палили, було 34 $(72,3 \%)$ та жінок $-8(25 \%, \mathrm{p}=0,001)$. Серед осіб без діагностованого ХОЗЛ палили 21 чоловік $(63,6 \%)$ та 2 жінки $(8,3 \%),(\mathrm{p}=0,001)$ (рис. 2).

Вплив паління на формування патологічних змін, що сприятимуть розвитку захворювання, визначається тривалістю паління (стаж) та кількістю цигарок, що пацієнт палить протягом доби. Сучасним критерієм впливу паління на здоров'я $є$ індекс паління. Встановлено, що стаж паління (у

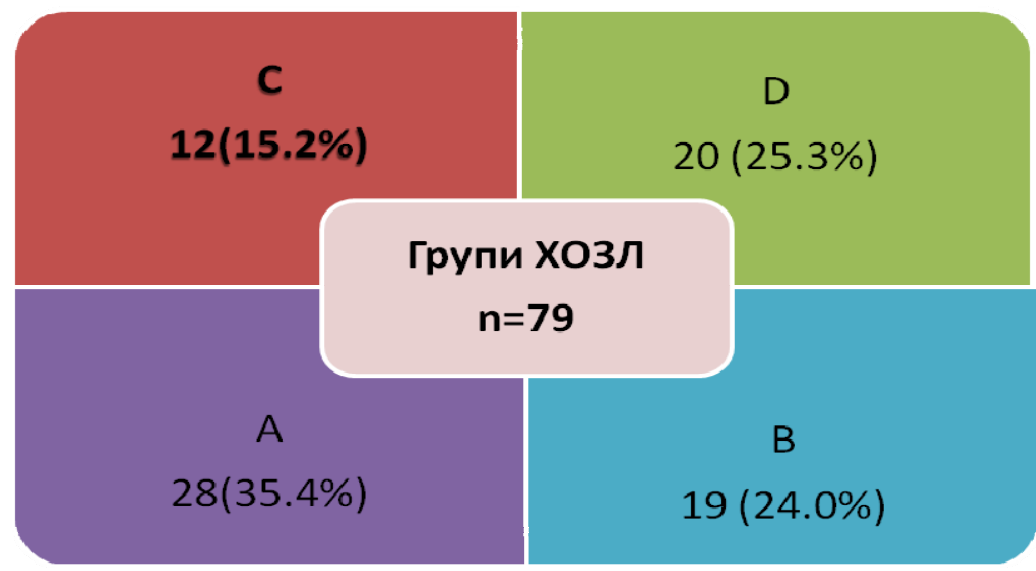

Рис. 6. Клінічні групи хронічного обструктивного захворювання легень у осіб із вперше виявленим захворюванням

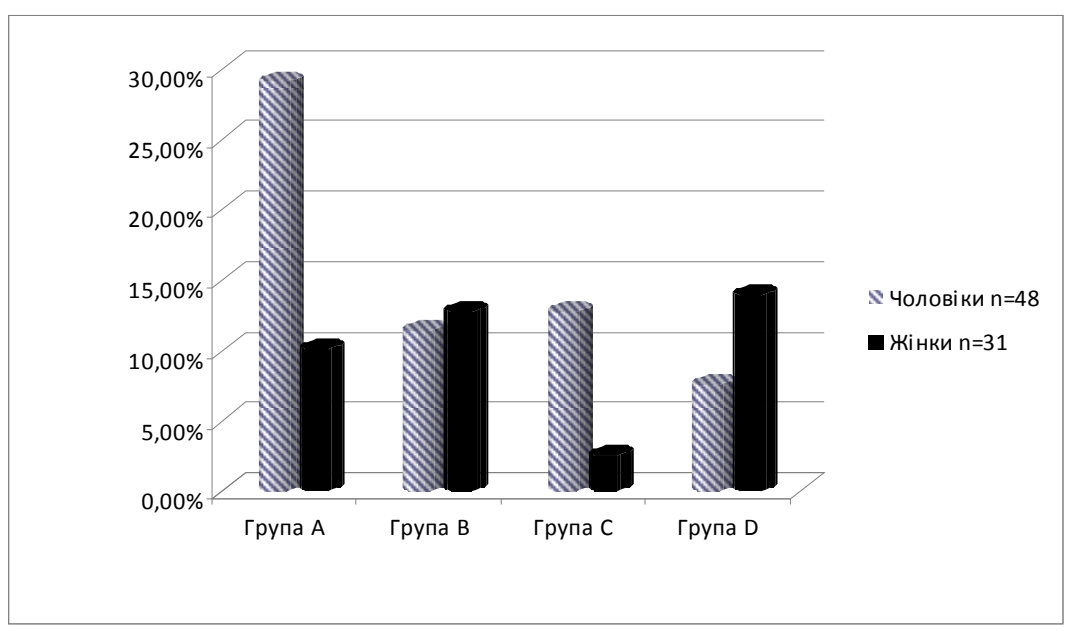

Рис. 7. Клінічні групи хронічного обструктивного захворювання легень у осіб із вперше виявленим захворюванням статева структура

Таблиця 2

Порівняння оцінки параметрів якості життя серед осіб із вперше виявленим хронічним обструктивним захворюванням легень та без верифікованого діагнозу в різних статевих групах

\begin{tabular}{|c|c|c|c|c|c|c|}
\hline \multirow{2}{*}{ Показники } & $\begin{array}{c}\text { Пацієнти з вперше виявленим } \\
\text { ХОЗЛ, } \mathrm{n}=79\end{array}$ & \multirow{2}{*}{$\mathrm{P}$} & \multicolumn{2}{|c|}{$\begin{array}{c}\text { Пацієнти без встановленого } \\
\text { ХОЗЛ, } \mathrm{n}=57\end{array}$} & \multirow{2}{*}{ Р } \\
\cline { 2 - 3 } & $\begin{array}{c}\text { Чоловіки } \\
(\mathrm{n}=47)\end{array}$ & $\begin{array}{c}\text { Жінки } \\
(\mathrm{n}=32)\end{array}$ & & $\begin{array}{c}\text { Чоловіки } \\
(\mathrm{n}=33)\end{array}$ & $\begin{array}{c}\text { Жінки } \\
(\mathrm{n}=24)\end{array}$ & \\
\hline Фізичне здоров'я & $63(50 ; 72)$ & $64(50 ; 80)$ & 0,49 & $72(55 ; 80)$ & $72(57 ; 80)$ & 0,61 \\
\hline Психічне здоров'я & $52(45 ; 58)$ & $55(47 ; 65)$ & 0,26 & $55(45 ; 70)$ & $56(45 ; 71)$ & 0,95 \\
\hline Загальний стан & $56(46 ; 66)$ & $53(45 ; 66)$ & 0,63 & $62(54 ; 66)$ & $61(47 ; 66)$ & 0,62 \\
\hline
\end{tabular}

Примітка. 1. Порівняння відсотків між групами проведено за критерієм $\chi^{2} .2$. Порівняння величин загального бала між групами проведено за Mann-Whithney U test. 3. Різниця достовірна при $p<0,05$ 
Original research

тому числі і серед колишніх курців) становив $(15,07 \pm 0,95)$ років у пацієнтів із вперше виявленим ХОЗЛ та $(18,1 \pm 1,97)$ - в осіб без встановленого діагнозу. Достовірної різниці між цими показниками в даних групах не виявлено $(\mathrm{p}=0,50)$.

Середня кількість сигарет за добу становила $16(13 ; 20)$ у групі пацієнтів 3 ХОЗЛ та $14(10 ; 18)$ в осіб без ХОЗЛ. Індекс паління становив 13,5 та 11,2 пачко/років відповідно в осіб з ХОЗЛ та без ХОЗЛ (рис. 3).

Розподіливши пацієнтів за ступенем тяжкості ХОЗЛ бачимо, що найбільше пацієнтів було 3 GOLD 2 - 26 осіб (32,9 \%) та GOLD 3 - 28 осіб (35,40 \%). Найменш численна група GOLD 4 - 4 пацієнти - (5,1 \%) (рис. 4).

Статева структура пацієнтів із вперше виявленим ХОЗЛ залежно від ступеня тяжкості була такою: iз GOLD 1 діагностовано 15 чоловіків $(19,0 \%)$ та 6 жінок $(7,6 \%)$; із GOLD 2 - 14 чоловіків $(17,7 \%)$ та 12 жінок (15,2\%); із GOLD 3 16 чоловіків (20,2\%) та 12 жінок $(15,2 \%)$; із GOLD 4 - 2 чоловіки (2,5 \%) та 2 жінки (2,5\%) .

Ступінь задишки оцінена за модифікованою шкалою тяжкості задишки Медичної дослідної ради і встановлено, що достовірно вищі бали мали пацієнти з групи ХОЗЛ - середній бал становив $1,44 \pm 0,07$, у той час як у групі без виявленого за-

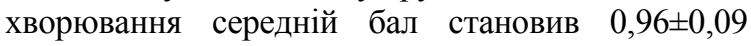
$(\mathrm{p} \leq 0,0001)$. Ступінь задишки в жінок у групі 3 ХОЗЛ - $2(1 ; 2)$ був достовірно вищий, ніж у чоловіків $1(1 ; 2)(\mathrm{p}=0,009)$. Достовірної різниці між чоловіками та жінками у групі без ХОЗЛ не встановлено. Серед пацієнтів із встановленим діагнозом найчисленніші були групи, до яких віднесені пацієнти, що набрали 1 та 2 бали - по 38 осіб $(48,1 \%)$, що характерно як для чоловіків, так і для жінок (рис. 5).

За тестом САТ достовірно вищі бали були у групі осіб зі встановленим діагнозом, ніж у групі без ХОЗЛ - середній бал становив - 18,8 $\pm 0,8$ та $12,7 \pm 1,0$ відповідно $(\mathrm{p}=<0,0001)$. Кількість балів за тестом САТ у жінок - $22(16 ; 27)$ у групі з ХОЗЛ була достовірно вища, ніж у чоловіків 18(13;22) $(\mathrm{p}=0,03)$. Достовірної різниці між чоловіками та жінками у групі без ХОЗЛ не встановлено.

Ми розподілили пацієнтів із вперше виявленим ХОЗЛ на клінічні групи. До групи А - низький ризик несприятливих подій у майбутньому, невелика кількість симптомів - віднесено 28 осіб (35\%); група В - низький ризик несприятливих подій у майбутньому, велика кількість симптомів - 19 осіб (24\%); група С - високий ризик несприятливих подій у майбутньому, невелика кількість симптомів 12 (15\%); група Д - 20 осіб (25\%). Отже, варто відзначити, що серед осіб із вперше виявленим ХОЗЛ майже 50 \% (група В і Д) пацієнтів мали велику кількість симптомів, що не було раніше оцінено лікарями, які проводили медичні огляди (рис. 6).

Статева структура пацієнтів така - до групи А віднесено $23(29,1 \%)$ чоловіки та 8 (10,1\%) жінок. До групи В - 9 (11,4 \%) чоловіків та 10 (12,7 \%) жінок. До групи С - 10 (12,7 \%) чоловіків та 2 (2,5 \%) жінки. До групи D - 6 (7,6 \%) чоловіків та 11 (12,7 \%) жінок (рис. 7).

Параметри якості життя дозволяють об'єктивізувати стан хворого, а також оцінити наслідки захворювання(табл. 2).

Оцінка основних параметрів якості життя (табл. 2) дозволяє бачити дещо нижчі показники якості життя у пацієнтів з ХОЗЛ, ніж у пацієнтів без даної патології. При оцінці фізичного статусу (ФС) середня кількість балів у пацієнтів з ХОЗЛ становила 72, у той час як у пацієнтів без ХОЗЛ 65 балів. Суттєвої різниці між чоловіками та жінками у цих групах не було - у групі з ХОЗЛ середня кількість балів становила $63(50 ; 72)$, а в жінок - 64 (50; 80); У групі без ХОЗЛ - відповідно $72(55 ; 80)$ у чоловіків та $72(57 ; 80)$ у жінок.

Щодо психічного статусу (ПС) бали розподілилися таким чином - у пацієнтів з ХОЗЛ - 56 балів - чоловіки - $52(45 ; 58)$ та жінки - 55 (47; $65)$, у пацієнтів без встановленого діагнозу 55 балів - у чоловіків 55 (45; 70), у жінок - 56 (45; 71).

При оцінці загального статусу (3С): у пацієнтів з ХОЗЛ 62 бали чоловіки набрали 56(46;66) балів у середньому, жінки - 53 (45; 66), а в пацієнтів без даної патології - 56 балів - у чоловіків $62(54 ; 66)$, а в жінок - $61(47 ; 66)$.

Проте варто відзначити відсутність достовірної різниці показників основних параметрів якості життя у групах пацієнтів з ХОЗЛ та без ХОЗЛ.

\section{Висновки}

1. Діагностика хронічного обструктивного захворювання легень належить до найбільш актуальних та складних у роботі лікаря загальної практики, що визначається, з одного боку, збільшенням кількості осіб старших вікових груп, що мають цілу низку факторів ризику, та з іншого методологічних підходів щодо діагностики захворювання.

2. Серед осіб, які регулярно проходять медичні огляди, 216 осіб (41,1 \%), за результатами анкетування, мають високу вірогідність хронічного обструктивного захворювання легень.

3. У $79(58,1 \%)$ пацієнтів, за результатами спірографії, виявлено зниження індексу Тифно (ОФВ1/ЖЕЛ) менше 70 \%, на підставі чого вперше встановлений діагноз хронічного обструктивного захворювання легень.

4. У групі осіб, які регулярно проходять медичні огляди, не діагностоване хронічне обструктивне захворювання легень спостерігалося у 14,9 \% випадків і супроводжувалося кашлем, задишкою, утрудненим диханням, що не були оцінені лікарями. У 59,0 \% хворих діагностовано хронічне обструктивне захворювання легень групи А та B, а в $41 \%$ осіб - групи C та D.

Перспективи подальших досліджень. Отже, наразі є доцільним створення простих скрині- 


\section{Оригінальні дослідження}

нгових алгоритмів відбору пацієнтів для наступного спірографічного обстеження, яке має стати одним із звичних у практиці не лише пульмонолога, а насамперед, лікаря сімейної медицини.

\section{Список літератури}

1. Фещенко ЮИ, Ящина ЛА, Дзюблик АЯ, Гаврисюк ВГ. Актуальные проблемы лечения больных хроническим обструктивным заболеванием легких. Здоров'я України. 2011; 6:10-11.

2. Kim SJ. Chronic obstructive pulmonary disease (COPD) is associated with systemic inflammation. International Journal of Tuberculosis and Lung Disease. 2011; 15 (9): 1265-70.

3. Bourbeau J. Preventing Hospitalization for COPD Exacerbations. Seminars in Respiratory and Critical Care Medicine. 2010 ; 31 (3): 313-20.

4. Sidney S, Sorel M, Quesenberry C, DeLuise C, Lanes S, Eisner MD. COPD and Incident Cardiovascular Disease Hospitalizations and Mortality. Kaiser Permanente Medical Care Program. Chest. 2005; 128 (4): 2068-75.

5. Мостовой ЮМ, Распутіна ЛВ, Черепій НВ. Діагностика симптомів хронічного обструктивного захворювання легень за даними анкетування. Медицина сьогодні і завтра. 2015; 2(67) : 59-65.

6. Rashton L. Occupational causes of obstructive pulmonary disease. Reviews on Environmental Health. 2007; 22 (3): 195-212.

7. Черепій НВ. Діагностика факторів ризику хронічного обструктивного захвоювання легень за даними анкетування осіб організованого колективу. Вісник BНМУ. 2015; 19: 448-52.

8. Наказ МОЗ України від 27.06.2013 № 555 «Про затвердження та впровадження медико-технологічних документів зі стандартизації медичної допомоги при хронічному обструктивному захворюванні легень». Режим доступу: http://www.moz.gov.ua/ua/portal/ dn_20130627_0555.html

9. Наказ МӦ України від 3.08.2012 p. №601 «Про затвердження та впровадження медикотехнологічних документів зі стандартизації медичної допомоги при припиненні вживання тютюнових виробів». Режим доступу: http://www.moz.gov.ua/ua/portal/ dn_20120803_601.html

10. Линник МІ. Порівняльні дані про розповсюдженість хвороб органів дихання і медичну допомогу хворим на хвороби пульмонологічного профілю в Україні за 2008-2010 рр. Київ; 2011. 34 с.

11. Реброва ОЮ. Статистический анализ медицинских данных. Применение пакета прикладних программ STATISTICA. М. Медиа Сфера; 2006. 269 с.

\section{References}

1. Feshchenko Yu, Yashina L, Dzublik A, Gavrisuk V. Aktual'nye problemy lechenyia bol'nykh khronycheskym obstruktyvnym zabolevanyem lehkykh [ Actual problems of treatment of patients with chronic obstructive pulmonary disease].. Health Of Ukraine. 2011; 6: 10-11. (in Ukrainian).

2. Kim SJ. Chronic obstructive pulmonary disease (COPD) is associated with systemic inflammation. International Journal of Tuberculosis and Lung Disease. 2011; 15 (9): 1265-70.

3. Bourbeau J. Preventing Hospitalization for COPD Exacerbations. Seminars in Respiratory and Critical Care Medicine. 2010; 31 (3): 313-20.

4. Sidney S, Sorel M, Quesenberry CP, DeLuise, C, Lanes, S, Eisner MD. (2005). COPD and Incident Cardiovascular Disease Hospitalizations and Mortality: Kaiser Permanente Medical Care Program. Chest. 2005; 128 (4): 2068-75.

5. Mostovoy Yu, Rasputina L, Cherepiy N. Diahnostyka symptomiv khronichnoho obstruktyvnoho zakhvoriuvannia lehen' za danymy anketuvannia [Diagnosis of symptoms of chronic obstructive pulmonary disease according to the survey]. Medicine today and tomorrow. 2015; 2 (67): 59-65. (in Ukrainian).

6. Rashton L. (2007). Occupational causes of obstructive pulmonary disease. Reviews on Environmental Health. 2007; 22 (3): 195-212.

7. Cherepiy N. Diahnostyka faktoriv ryzyku khronichnoho obstruktyvnoho zakhvoiuvannia lehen' za danymy anketuvannia osib orhanizovanoho kolektyvu [Diagnosis of risk factors for chronic obstructive pulmonary disease according to the survey of persons organized team]. Visnyk VNMU. 2015; 19(2):448-52. (in Ukrainian).

8. Nakaz MOZ Ukrainy vid 27.06.2013 № 555 «Pro zatverdzhennya ta vprovadzhennya mediko-tekhnologichnyh dokumentiv zi standartyzatsii medychnoi dopomogy pry khronichnomu obstruktyvnomu zakhvoruvanni legen». Available at: http://www.moz.gov.ua/ua/portal/ dn_20130627_0555.html

9. Nakaz MOZ Ükrainy vid 3.08.2012 №601 «Pro zatverdzhennya ta vprovadzhennya mediko-tekhnologichnyh dokumentiv zi standartyzatsii medychnoi dopomogypry pry pynenni vzhyvannya tyutyunovykh vyrobiv». Available at: http://www.moz.gov.ua/ua/portal/dn_20120803_601.html

10. Linnyk MI. Porivnial'ni dani pro rozpovsiudzhenist' khvorob orhaniv dykhannia i medychnu dopomohu khvorym na khvoroby pul'monolohichnoho profiliu v Ukraini za 2008-2010 rr. [Comparative data on the prevalence of respiratory diseases and medical care of patients with diseases of pulmonary profile in Ukraine in 2008-2010]. Kyiv; 2011. 34 s. (in Ukrainian).

11. Rebrova O. Statystycheskyi analyz medytsynskykh dannkh. Prymenenye paketa prykladnykh prohramm STATISTICA Statistical analysis of medical data. [Application of software package STATISTICA]. Moscow: Mediasfera; 2006. 269 s. (in Russian).

\section{Відомості про автора:}

Черепій Наталія Вікторівна - аспірант кафедри пропедевтики внутрішньої медицини ВНМУ імені М.I. Пирогова, Вінниця, Україна.

Сведения об авторе:

Черепий Наталья Викторовна - аспирант кафедры пропедевтики внутренней медицины ВНМУ имени М.И. Пирогова, Винница, Украина.

\section{Information about the author:}

Cherepii Natalia - PhD student of the department of propaedeutics of internal medicine of M.I. Pirogov National Medical University, Vinnytsia, Ukraine. 